UDC: $632.1: 635.2$

\title{
SCREENING OF POTATO VARIETIES FOR MULTIPLE RESISTANCE TO SYNCHYTRIUM ENDOBIOTICUM IN THE WESTERN REGION OF UKRAINE
}

\author{
A. G. Zelya ${ }^{1 *}$, G. V. Zelya ${ }^{1}$, T. M. Oliynyk ${ }^{2}$, L. A. Pylypenko ${ }^{3}$, M. P. Solomiyciuk ${ }^{1}$, \\ R. O. Kordulean ${ }^{1}$, A. M. Skoreyko ${ }^{1}$, Yu. M. Bunduc ${ }^{1}$, V. M. Ghunchak ${ }^{1}$ \\ ${ }^{1}$ Ukrainian Scientific Research Plant Quarantine Station, Institute of Plant Protection, NAAS, Boyany \\ ${ }^{2}$ Institute for Potato Research, NAAS, Nemishaeve \\ ${ }^{3}$ National Academy of Agrarian Sciences of Ukraine, Kyiv \\ *e-mail:ukrndskr@gmail.com,liliya.pylypenko@gmail.com
}

Received September 06, 2018 / Received October 06, 2018 / Accepted November 21, 2018

\begin{abstract}
Aim. To evaluate potato breeding material for resistance to pathotypes of Synchytrium endobioticum (Schilbersky) Percival (1909) known to be present in Ukraine (pathotypes $1\left(D_{1}\right), 11,13,18$ and 22); to identify resistant registered and potential varieties for the usage in the national wart disease eradication programs and to recommend these selected (potential and registered) potato varieties for the breeding program targeted on the development of multiple resistance against pathotypes of $S$. endobioticum present in Ukraine. Methods. Evaluation of the potato breeding material and registered potato varieties for the resistance against common pathotype $1\left(\mathrm{D}_{1}\right)$ and four aggressive pathotypes of S. endobioticum (pathotypes 11, 13, 18 and 22) in climatic chamber and greenhouse tests of Ukrainian Scientific Research Plant Quarantine Station of Institute of Plant Protection NAAS (Boyany, Ukraine) following the Spieckermann and Glynne-Lemmerzahl methods (EPPO Standard PM7/28(2)). Field trials on naturally infected soils were conducted according to standard methods adapted to national requirements in the area of Chernivtsi, Zakarpattia and Ivano-Frankivsk regions. Results. 3,736 samples of potato breeding material from six breeding institutions of Ukraine were tested for resistance against S. endobioticum during 2011-2017 in the western region of the country. Among all samples tested, 3,389 were identified as resistant to the widely spread pathotype 1 in the preliminary climatic chamber and greenhouse tests, and 130 of them proved to be resistant under field conditions. Five out of 41 Ukrainian registered potato varieties (Bazys, Hlazurna, Solokha, Bozhedar and Santarka) were found to be resistant to all 5 pathotypes tested ( $\left(\mathrm{D}_{1}\right), 11,13,18$ and 22). Conclusions. The 130 samples of potato breeding material (which were found to be resistant against the common pathotype 1 of $S$. endobioticum in the laboratory, greenhouse as well as in the field trials) were recommended for the state variety registration and further usage in an eradication program to localize potato wart outbreaks of the western part of Ukraine. The screening tests revealed that the national breeding program targeted on resistance against $S$. endobioticum pathotype 11 was the most effective (49 \% of samples tested proved to be resistant against this pathotype), whereas it was the least effective against pathotype 18 , namely only $30 \%$ of samples resistant. It was speculated that such a dissimilarity may be related to the differences in the genetic material used in the breeding process at various institutions, and which may be the subject of further analysis in order to improve the results of breeding programs. The already registered potato varieties Bazys, Hlazurna, Solokha, Bozhedar and Santarka which were found to have a multiple resistance to common pathotype 1 and four local aggressive pathotypes of $S$. endobioticum (11, 13, 18 and 22) were recommended for use in the breeding process as sources of resistance and also for the eradication programs in the western region of Ukraine, where $S$. endobioticum is mostly distributed (2409 hectares or $98 \%$ ).
\end{abstract}

Keywords: potato, wart disease, pathotypes, screening, resistance, breeding.

DOI: https://doi.org/10.15407/agrisp5.03.003

(C) A. G. ZELYA, G. V. ZELYA, T. M. OLIYNYK,

L. A. PYLYPENKO, M. P. SOLOMIYCIUK,

R. O. KORDULEAN, A. M. SKOREYKO, Yu. M. BUNDUC,

V. M. GHUNCHAK, 2018

\section{INTRODUCTION}

Potato is one of the most valuable and important agricultural crops, and ranks fourth in the world after corn, 


\section{ZELYA et al.}

wheat and rice in total volume [1]. In 2017, the total volume of harvested potato in Ukraine was 22 million tons and its cultivated area ca. 1.3 million ha [2]. These latter figures demonstrating the relevance of potato in national food security.

The potato plant is a host for a noxious obligate pathogen, namely the zoosporic chytrid fungus Synchytrium endobioticum (Schilbersky) Percival 1909, causing the so-called potato wart disease, which is subject to quarantine regulations in many countries of the world [3-6]. According to the data of the European and Mediterranean Plant Protection Organization (EPPO), as of January 2018 S. endobioticum is commonly found in 34 countries, including the Falkland Islands (Great Britain) and the Faroe Islands (Denmark) [7].

The quarantine status of the agent is conditioned by its ability to decrease the yield of the infected plants, even up to $100 \%$, which is especially notable for potato cultivation in small holdings [8]. This may be explained both by a high damaging ability of the agent but also by its abilities of adapting to unfavorable environmental conditions, including the formation of new and more aggressive pathotypes [6] and the extremely long survival, more than 46 years, of its thick-walled resting spores (winter sporangia) in the soil [9].

Long-term observations of spreading and damaging abilities of $S$. endobioticum in the territory of the European part of the continent demonstrated that most frequently the sources of aggressive pathotypes of the agent were manifested in the valleys of mountainous regions, located at the height of more than $400 \mathrm{~m}$ above sea level in the zone of continental climate, where in winter the ground freezes at least for several weeks, and the amount of precipitation within the vegetation period exceeds $600 \mathrm{~mm}$ [6]. It is also known that long-term cultivation of resistant varieties of potato, especially in case of a one-crop system, precedes the appearance of aggressive pathotypes of S. endobioticum $[6,8]$.

The above-mentioned conditions for development of new pathotypes of $S$. endobioticum prevail unfortunately in the mountainous areas of the western regions of Ukraine, where distribution of S. endobioticum has been registered since 1961. Whithin this part of the country five pathotypes have been observed till now: common pathotype $1\left(D_{1}\right)$, and four aggressive ones, namely pathotype 11 (the village of Maydan, Mizhhirya district, Lviv region), 13 (the town of Rakhiv, Zakarpattia region), 18 (the village of Yasinia, Rakhiv district, Zakarpattia region) and 22 (Bystrets, Verk- hovyna district, Ivano-Frankivsk region) $[8,10]$ on a total area of 2409 hectares, which constitutes $98 \%$ of S. endobioticum distribution area in Ukraine [11]. So far the breeding of potato wart-resistant varieties is the only economically viable and efficient means of controlling this quarantine organism [12].

There are current data on global spreading of at least 39 pathotypes of $S$. endobioticum, although most breeding programs aim only at the most wide-spread ones namely pathotypes $1\left(\mathrm{D}_{1}\right), 2,6$ and 18 [10]. Only several potato varieties with multiple resistance exists to date, but they were not widely introduced [13-15]. Evidently, a valuable acquisition of new potato varieties should be the combination of the feature of (multiple) resistance to (local) pathotypes of $S$. endobioticum and high indices of economically viable characteristics.

The aims of the study were 1) to evaluate potato breeding material for resistance to pathotypes of Synchytrium endobioticum (Schilbersky) Percival known to be present in Ukraine (pathotypes 1, 11, 13, 18 and $22)$;2) to select potential new varieties on the basis of the results and 3) to identify multiple resistance in registered varieties for their use in national wart disease eradication programs and in national breeding programs.

\section{MATERIALS AND METHODS}

In 2011-2017, 3,736 potato samples of potato breeding material from six breeding institutions and 41 registered potato varieties from three breeding institutions in Ukraine were used in the study.

The evaluation of the potato breeding material and registered potato varieties for resistance to common and aggressive pathotypes of S. endobioticum was conducted under climatic chamber, greenhouse and field conditions using the following methods.

The method of infecting potato tubers with winter zoospores which were in a dormant state. The contamination of potato samples with zoospores from germinated winter zoosporangia of potato wart was conducted by the modified method of Spieckermann and Kothoff $(1924)$ [2,13] under greenhouse conditions. The soil samples, collected from infested fields, were each mixed with perlite in $1: 1$ ratio to obtain an average level of 40-50 winter zoosporangia per $1 \mathrm{~g}$ of soil. The mixture was placed into plastic containers $(30 \times 40 \mathrm{~cm})$, and the potato varieties under investigation were planted therein. The experiment was performed in three repeats; potato varieties Poliska rozheva and Lorkh, susceptible to all presently known local 
pathotypes of S. endobioticum, were used as a control. The containers were kept at $17-18{ }^{\circ} \mathrm{C}$, and $70-80 \%$ relative humidity $(\mathrm{RH})$ in a $12 / 12$ day/night regime; watered every three days, loosened once a week and the reaction of potato tubers present in the samples to infecting with potato wart was determined after 75 days (Fig. 1). For this reason, the plants were dug out of containers and the warts on all tubers of each experimental sample and control varieties of potato were counted. The results were deemed reliable if the not less than $75 \%$ of control variety plants showed disease symptoms.

The method of infecting potato tuber sprouts with summer zoospores from freshly formed warts. The resistance of plants to summer zoospores of the pathogen, obtained from freshly formed warts, was evaluated by the method of Glynne-Lemmerzahl $[2,10]$ adapted as following [13]: a paper ring was fixed around the sprout part of a potato tuber using a warmed-up mixture of paraffine and vaseline $(1: 1)$ for this purpose. Distilled water was poured into the ring with the addition of $0.5 \mathrm{cc}$ of the recent wart, containing summer zoospores of S. endobioticum (Fig. 2). The samples were incubated in the climatic chamber at $11{ }^{\circ} \mathrm{C}$ without any illumination to stimulate the infection process. Paper rings were removed from potato tubers $24 \mathrm{~h}$ later and the incubation was continued in the climatic chamber at $17-18{ }^{\circ} \mathrm{C}$ for 20 days in the darkness. After this period, the response of potato samples to being infected with the pathogen was determined (Fig. 3). Potato sprouts were analyzed under a microscope BioLight 300 (DELTA optical, Poland) to determine the degree of damage according to the following scale, adapted after $[13,16]$ :

1 point - necrotic tissue, rare sori (up to 5);

2 points - scattered sori (if exceeding 5);

3 points - dense sori without the deformation of a potato sprout;

4 points - dense sori with the deformation of a potato sprout;

5 points - deformation of a sprout, a wart.

The total score $(\mathrm{M})$ of the potato variety damage was determined using the formula:

$$
\mathrm{M}=[1 \mathrm{a}+2 \mathrm{~b}+3 \mathrm{c}+4 \mathrm{~d}+5 \mathrm{e}] / \mathrm{n},
$$

where $a, b, c, d, e-$ number of tubers which received the relevant points for the damage; 1, 2, 3, 4, 5- points for the damage; $n$ - number of infected potato tubers of the experimental sample.

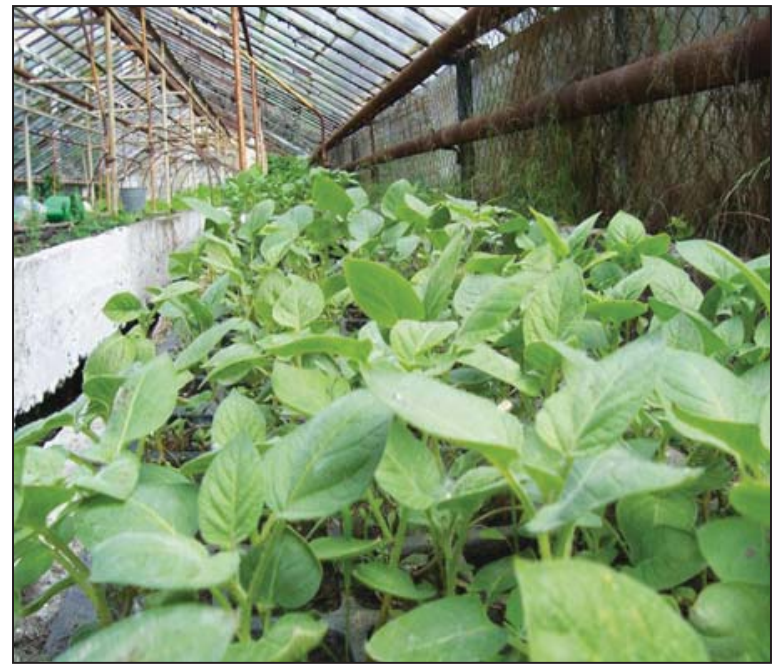

Fig. 1. Testing breeding material of potato under greenhouse conditions, using winter zoospores of Synchytrium endobioticum

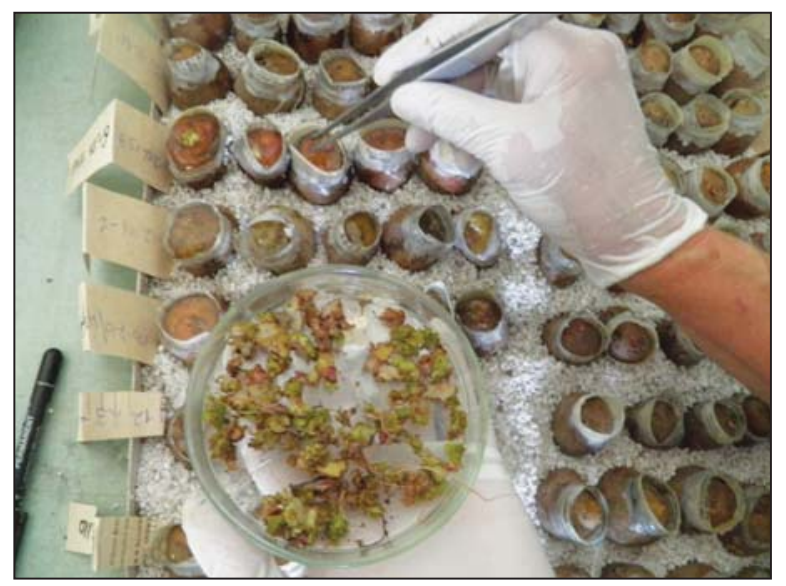

Fig. 2. Infecting potato samples using summer zoospores of Synchytrium endobioticum

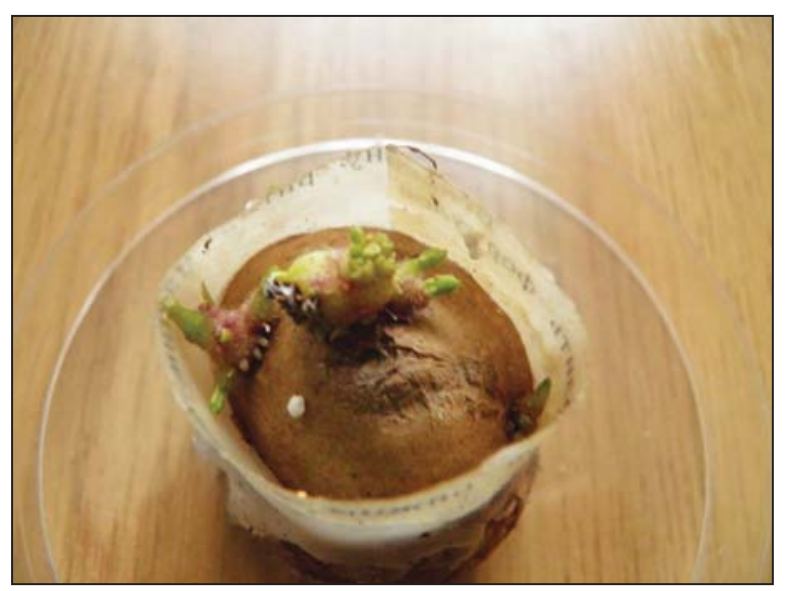

Fig. 3. Symptoms of potato wart after artificial infection of potato variety Poliska rozheva with summer zoospores of Synchytrium endobioticum 


\section{ZELYA et al.}

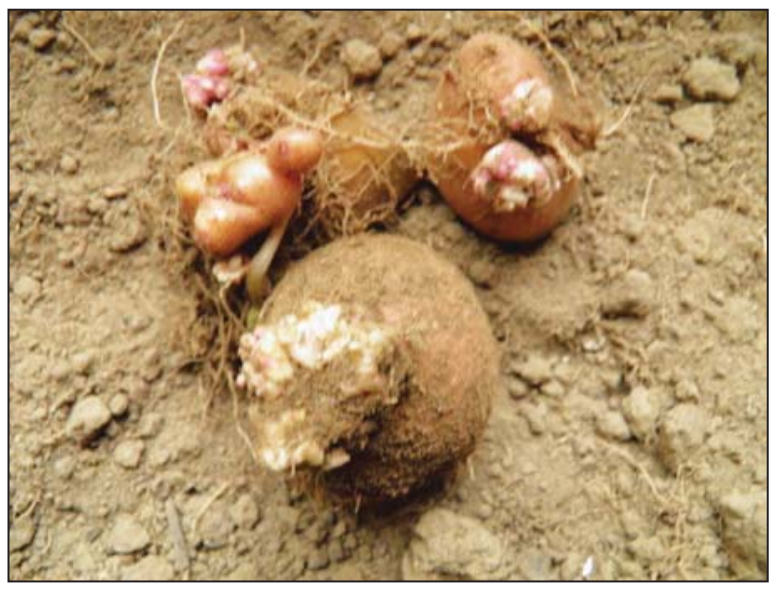

Fig. 4. Symptoms of wart disease after artificial infection of potato variety Poliska rozheva with winter zoospores of Synchytrium endobioticum

In case of determining the total score of the damage to be 1,2 or 3 , the experimental sample was considered to be resistant to $S$. endobioticum ( $\mathrm{R}$ - resistant); points 4 or 5 - susceptible ( $\mathrm{S}$ - susceptible).

Studying the resistance of potato breeding material to potato wart under field conditions. The evaluation and screening of breeding potato material and registered Ukrainian potato varieties under field conditions were conducted in natural infected soil in the areas of pathogen spreading in the western region of Ukraine: to common pathotype $1\left(\mathrm{D}_{1}\right)$ of $S$. endobioticum - in the village of Berehomet, Vyzhnytsia district, Chernivtsi region; to aggressive pathotypes - in the village of Maydan, Mizhhirya district, Lviv region (pathotype 11), in the town of Rakhiv (pathotype 13), in the village of Yasinia (pathotype 18), Rakhiv district, Zakarpattia region, and in the village of Bystrets (pathotype 22),
Verkhovyna district, Ivano-Frankivsk region. The experiment was performed in three repeats; potato variety Poliska rozheva, susceptible to all the local pathotypes of $S$. endobioticum, was used as a control.

\section{RESULTS AND DISCUSSION}

Tests performed under climate chamber and greenhouse conditions in the years 2011-2017, aimed at evaluating the resistance of 3,736 potato samples to S. endobioticum, determined 3,389 samples to be resistant and 347 to be susceptible (Table 1, Fig. 4) to the pathogen (susceptible samples were excluded from further studies). Subsequently 130 resistant potential variety samples were admitted to the national field test program on the basis of resistance performance and their economically viable properties.

Screening 130 selected potential varieties from the tested breeding potato material, resistant to potato wart, under field conditions in the national test program. The resistance found under greenhouse and climatic chamber conditions of 130 potential potato varieties to common pathotype 1 of potato wart was confirmed by the field tests in the national test program which were conducted from 2011 to 2017 (Table 2).

Only three out of the 130 potential varieties under investigation (all three bred by the Institute for Potato Research, NAAS) showed resistance to all the local aggressive pathotypes (samples 08.40.14, 208ч.10 and F.15).

The remaining investigated samples differed in their response to the aggressive pathotypes of the pathogen, in particular, 64 samples were noted for their resistance to aggressive pathotype 11 (Mizhhirya); 59 samples -

Table 1. The results of the preliminary testing under greenhouse conditions of breeding potato material for resistance to common pathotype 1 of Synchytrium endobioticum (2011-2017)

\begin{tabular}{l|c|c|c}
\hline \multirow{2}{*}{ Institution name } & \multicolumn{3}{c}{ Number of potato samples } \\
\cline { 2 - 4 } & Total & Resistant & Susceptible \\
\hline Institute for Potato Research, NAAS of Ukraine & 1546 & 1368 & 178 \\
Institute of Agriculture of the Carpathian Region, NAAS & 205 & 191 & 14 \\
of Ukraine & 274 & 262 & 12 \\
Institute of Agriculture of Polissia, NAAS of Ukraine & 110 & 89 & 21 \\
Mountainous Scientific Division of the Institute of & 633 & 589 & 44 \\
Agriculture of the Carpathian Region, NAAS of Ukraine & 968 & 890 & 78 \\
PJSC SPA "Chernihivelitkartoplia" & 3736 & 3389 & 347 \\
Polissia Experimental Department IP NAAS & & & \\
Total & &
\end{tabular}


to pathotypes 13 and 22 (Rakhiv and Bystrets respectively); 39 samples - to pathotype 18 (Yasinia) (Table 2; Fig. 5-6).

In general, most positive results were demonstrated by the breeding program, aimed at obtaining potato varieties, resistant to aggressive pathotype 11 (49\% of investigated varieties demonstrated their resistance to this pathotype) and the most efficient - to pathotype 18 (30\% of resistant investigated varieties).

The results obtained were given to the institutions, wherefrom the breeding material had originated, with the indication of resistance characteristics to $S$. endobioticum and recommendations of their registration and stimulation of their further introduction in the spreading areas of $S$. endobioticum in Ukraine

Forty-one already registered Ukrainian potato varieties, selected by their economically viable properties, were also additionally studied for their resistance to common and local aggressive pathotypes of $S$. endobioticum, present in Ukraine.

According to our studies, all investigated varieties were resistant to common pathotype 1 (Table 3 ), whereas the control varieties Poliska rozheva and Lorkh were susceptible and showed clear disease symptoms.

24 varieties out of the 41 studied were also found to be resistant to aggressive pathotype 11 (Mizhhirya); 13 - to pathotype 13 (Rakhiv); 9 - to pathotype 18 (Yasinia) and 16 varieties to pathotype 22 (Bystrets).

Eight varieties (Oberih, Kimmeria, Chervona ruta, Fantasia, Poliske dzherelo, Vodohray, Obrii, Dobrochyn) were resistant to two aggressive pathotypes, six varieties were resistant to three aggressive pathotypes

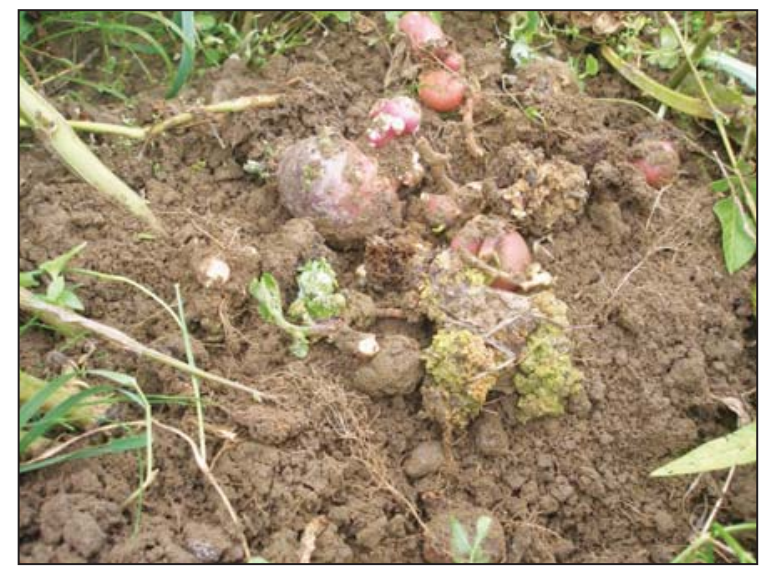

Fig. 5. Potato variety Poliska rozheva, infected by common pathotype 1 of Synchytrium endobioticum (under field conditions, in the national test program) Berehomet, Vyzhnytsia district, Chernivtsi region)

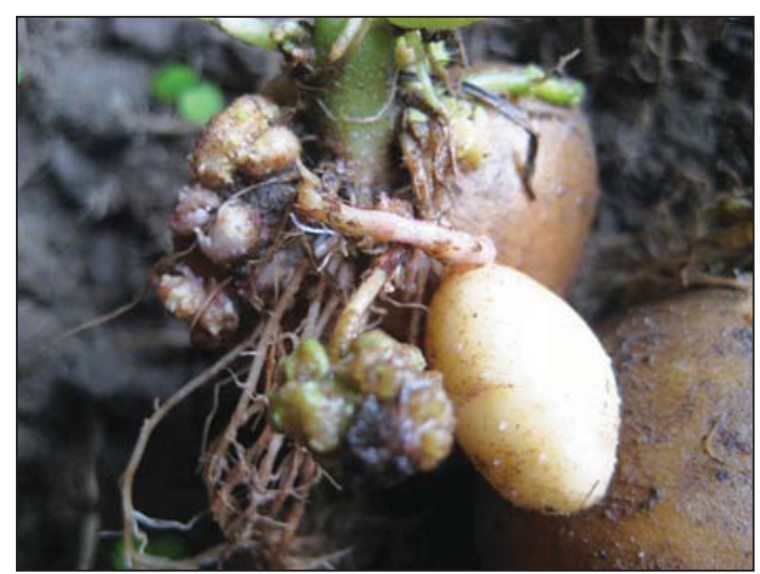

Fig. 6. Potato breeding sample П08.86-11, infected by aggressive pathotype 18 of Synchytrium endobioticum (Yasinia) (under field conditions, in the national test program - the village of Yasinia, Rakhiv district, Zakarpattia region)

Table 2. The results of the state test of potato for resistance to local pathotypes of Synchytrium endobioticum (2011-2017)

\begin{tabular}{|c|c|c|c|c|c|c|}
\hline \multirow{2}{*}{ Institution name } & \multirow{2}{*}{$\begin{array}{c}\text { Total } \\
\text { number } \\
\text { of } \\
\text { samples }\end{array}$} & \multicolumn{5}{|c|}{$\begin{array}{l}\text { Number (percentage) of samples, resistant to a specific } \\
\text { pathotype of Synchytrium endobioticum }\end{array}$} \\
\hline & & $\begin{array}{l}1(\mathrm{D} 1) \\
(\text { comm.) }\end{array}$ & $\begin{array}{c}11 \\
\text { (Mizhhirya) }\end{array}$ & $\begin{array}{c}13 \\
\text { (Rakhiv) }\end{array}$ & $\begin{array}{c}18 \\
\text { (Yasinia) }\end{array}$ & $\begin{array}{c}22 \\
\text { (Bystrets) }\end{array}$ \\
\hline Institute for Potato Research, NAAS of Ukraine & 59 & $59(100 \%)$ & $35(59 \%)$ & $23(39 \%)$ & $16(27 \%)$ & $31(53 \%)$ \\
\hline $\begin{array}{l}\text { Institute of Agriculture of the Carpathian Re- } \\
\text { gion, NAAS of Ukraine }\end{array}$ & 12 & $12(100 \%)$ & $3(25 \%)$ & $2(17 \%)$ & $3(25 \%)$ & $4(33 \%)$ \\
\hline $\begin{array}{l}\text { Mountainous Scientific Division of the Insti- } \\
\text { tute of Agriculture of the Carpathian Region, } \\
\text { NAAS of Ukraine }\end{array}$ & 17 & $17(100 \%)$ & $6(35 \%)$ & $3(18 \%)$ & $4(24 \%)$ & $5(29 \%)$ \\
\hline PJSC SPA Chernihivelitkartoplia & 8 & $8(100 \%)$ & $4(50 \%)$ & $3(38 \%)$ & $4(50 \%)$ & $3(38 \%)$ \\
\hline Polissia Experimental Department IP NAAS & 34 & $34(100 \%)$ & $17(50 \%)$ & $27(79 \%)$ & $12(35 \%)$ & $16(47 \%)$ \\
\hline Total & 130 & $130(100 \%)$ & $64(49 \%)$ & $59(45 \%)$ & $39(30 \%)$ & $59(45 \%)$ \\
\hline
\end{tabular}


ZELYA et al.

Table 3. The (degree of) response of existing, registered Ukrainian potato varieties, to infection with local pathotypes of S. endobioticum in the western region of Ukraine

\begin{tabular}{|c|c|c|c|c|c|c|}
\hline \multirow{3}{*}{ No. } & \multirow{3}{*}{ Variety name } & \multicolumn{5}{|c|}{ Resistance/Susceptibility (the degree of response to infection) } \\
\hline & & \multicolumn{5}{|c|}{ Synchytrium endobioticum pathotypes } \\
\hline & & 1 (D1) common & 11 (Mizhhirya) & 13 (Rakhiv) & 18 (Yasinia) & 22 (Bystrets) \\
\hline \multicolumn{7}{|c|}{ Institute for Potato Research, NAAS of Ukraine } \\
\hline 1. & Bazys & $\mathrm{R}(1,0)^{*}$ & $\mathrm{R}(1,6)$ & $\mathrm{R}(1,4)$ & $\mathrm{R}(2,0)$ & $\mathrm{R}(2,0)$ \\
\hline 2. & Hlazurna & $\mathrm{R}(1,4)$ & $\mathrm{R}(1,4)$ & $\mathrm{R}(1,4)$ & $\mathrm{R}(2,8)$ & $\mathrm{R}(2,0)$ \\
\hline 3. & Solokha & $\mathrm{R}(1,0)$ & $\mathrm{R}(1,4)$ & $\mathrm{R}(1,6)$ & $\mathrm{R}(2,0)$ & $\mathrm{R}(2,8)$ \\
\hline 4. & Kalynivska & $\mathrm{R}(1,6)$ & $\mathrm{S}(4,6)$ & $\mathrm{R}(2,0)$ & $\mathrm{R}(2,8)$ & $\mathrm{R}(2,0)$ \\
\hline 5. & Vernisazh & $\mathrm{R}(1,2)$ & $\mathrm{R}(1,6)$ & $\mathrm{S}(4,4)$ & $\mathrm{R}(1,4)$ & $\mathrm{R}(2,8)$ \\
\hline 6. & Khortytsia & $\mathrm{R}(1,4)$ & $\mathrm{R}(1,6)$ & $\mathrm{R}(1,2)$ & $\mathrm{R}(1,2)$ & $\mathrm{S}(4,4)$ \\
\hline 7. & Oberih & $\mathrm{R}(1,0)$ & $\mathrm{R}(1,2)$ & $\mathrm{R}(1,6)$ & $\mathrm{S}(4,6)$ & $\mathrm{S}(4,2)$ \\
\hline 8. & Kimmeria & $\mathrm{R}(1,2)$ & $\mathrm{R}(1,4)$ & $\mathrm{R}(1,4)$ & $\mathrm{S}(4,8)$ & $\mathrm{S}(4,6)$ \\
\hline 9. & Chervona ruta & $\mathrm{R}(1,4)$ & $\mathrm{R}(1,2)$ & $\mathrm{R}(1,6)$ & $\mathrm{S}(4,8)$ & $\mathrm{S}(4,4)$ \\
\hline 10. & Fantasia & $\mathrm{R}(1,2)$ & $\mathrm{R}(2,0)$ & $\mathrm{S}(4,6)$ & $\mathrm{S}(4,6)$ & $\mathrm{R}(2,8)$ \\
\hline 11. & Poliske dzherelo & $\mathrm{R}(2,8)$ & $\mathrm{S}(4,6)$ & $\mathrm{R}(2,0)$ & $\mathrm{S}(4,0)$ & $\mathrm{R}(2,0)$ \\
\hline 12. & Vodohrai & $\mathrm{R}(2,8)$ & $\mathrm{R}(2,8)$ & $\mathrm{S}(4,6)$ & $\mathrm{S}(4,8)$ & $\mathrm{R}(2,8)$ \\
\hline 13. & Obrii & $\mathrm{R}(1,6)$ & $\mathrm{R}(1,4)$ & $\mathrm{S}(4,4)$ & $\mathrm{S}(4,8)$ & $\mathrm{R}(2,0)$ \\
\hline 14. & Levada & $\mathrm{R}(1,6)$ & $\mathrm{R}(1,4)$ & $\mathrm{S}(4,4)$ & $\mathrm{S}(4,6)$ & $\mathrm{S}(4,4)$ \\
\hline 15. & Slovianka & $\mathrm{R}(2,8)$ & $\mathrm{R}(2,8)$ & $\mathrm{S}(4,6)$ & $\mathrm{S}(4,8)$ & $\mathrm{S}(4,6)$ \\
\hline 16. & Yavir & $\mathrm{R}(2,0)$ & $\mathrm{S}(4,4)$ & $\mathrm{S}(4,8)$ & $\mathrm{S}(4,8)$ & $\mathrm{S}(4,4)$ \\
\hline 17. & Lileia & $\mathrm{R}(2,8)$ & $\mathrm{S}(4,8)$ & $\mathrm{S}(4,6)$ & $\mathrm{S}(4,6)$ & $\mathrm{S}(4,8)$ \\
\hline 18. & Melodiia & $\mathrm{R}(2,0)$ & $\mathrm{S}(4,8)$ & $\mathrm{S}(4,6)$ & S $(4,6)$ & $\mathrm{S}(4,4)$ \\
\hline 19. & Serpanok & $\mathrm{R}(2,8)$ & $\mathrm{S}(4,6)$ & $S(4,6)$ & $\mathrm{S}(4,8)$ & $\mathrm{S}(4,4)$ \\
\hline 20. & Skarbnytsia & $\mathrm{R}(2,0)$ & $\mathrm{S}(4,6)$ & $\mathrm{S}(4,8)$ & $\mathrm{S}(4,6)$ & $\mathrm{S}(4,6)$ \\
\hline 21. & Zelenyi Hai & $\mathrm{R}(2,8)$ & $\mathrm{S}(4,8)$ & $\mathrm{S}(4,4)$ & $\mathrm{S}(4,8)$ & $\mathrm{S}(4,6)$ \\
\hline
\end{tabular}

Institute of Agriculture of the Carpathian Region, NAAS of Ukraine

\begin{tabular}{l|l|l|l|l|l|l}
\hline 22. & Dyvo & $\mathrm{R}(1,8)$ & $\mathrm{R}(2,8)$ & $\mathrm{R}(2,8)$ & $\mathrm{S}(4,8)$ & $\mathrm{R}(2,0)$ \\
23. & Lehenda & $\mathrm{R}(2,0)$ & $\mathrm{R}(2,0)$ & $\mathrm{S}(4,6)$ & $\mathrm{S}(4,6)$ & $\mathrm{S}(4,4)$ \\
24. & Mukachivska & $\mathrm{R}(2,8)$ & $\mathrm{S}(4,6)$ & $\mathrm{S}(4,6)$ & $\mathrm{S}(4,8)$ & $\mathrm{S}(4,6)$ \\
25. & Oksamyt-99 & $\mathrm{R}(2,0)$ & $\mathrm{S}(4,8)$ & $\mathrm{S}(4,8)$ & $\mathrm{S}(4,6)$ & $\mathrm{S}(4,8)$ \\
26. & Pikurovska & $\mathrm{R}(2,8)$ & $\mathrm{S}(4,6)$ & $\mathrm{S}(4,6)$ & $\mathrm{S}(4,8)$ & $\mathrm{S}(4,6)$ \\
27. & Uzhhorodska & $\mathrm{R}(1,8)$ & $\mathrm{S}(4,8)$ & $\mathrm{S}(4,6)$ & $\mathrm{S}(4,8)$ & $\mathrm{S}(4,4)$ \\
28. & Vira & $\mathrm{R}(2,8)$ & $\mathrm{S}(4,4)$ & $\mathrm{S}(4,6)$ & $\mathrm{S}(4,4)$ & $\mathrm{S}(4,6)$ \\
\hline
\end{tabular}

Polissia Experimental Department of the Institute for Potato Research, NAAS of Ukraine

\begin{tabular}{l|l|l|l|l|l|l}
\hline 29. & Bozhedar & $\mathrm{R}(1,0)$ & $\mathrm{R}(1,8)$ & $\mathrm{R}(1,8)$ & $\mathrm{R}(2,0)$ & $\mathrm{R}(2,0)$ \\
30. & Santarka & $\mathrm{R}(1,8)$ & $\mathrm{R}(1,6)$ & $\mathrm{R}(2,8)$ & $\mathrm{R}(2,8)$ & $\mathrm{R}(2,0)$ \\
31. & Malynska bila & $\mathrm{R}(1,6)$ & $\mathrm{R}(2,8)$ & $\mathrm{S}(4,8)$ & $\mathrm{R}(2,8)$ & $\mathrm{R}(2,0)$ \\
32. & Partner & $\mathrm{R}(1,8)$ & $\mathrm{R}(2,0)$ & $\mathrm{R}(3,0)$ & $\mathrm{S}(4,6)$ & $\mathrm{R}(2,8)$ \\
33. & Dobrochyn & $\mathrm{R}(2,0)$ & $\mathrm{R}(2,8)$ & $\mathrm{S}(4,6)$ & $\mathrm{S}(4,8)$ & $\mathrm{R}(2,0)$ \\
34. & Poliska yuvileina & $\mathrm{R}(2,8)$ & $\mathrm{R}(2,8)$ & $\mathrm{S}(4,8)$ & $\mathrm{S}(4,8)$ & $\mathrm{S}(4,6)$
\end{tabular}


End of Table 3

\begin{tabular}{|c|c|c|c|c|c|c|}
\hline \multirow{3}{*}{ No. } & \multirow{3}{*}{ Variety name } & \multicolumn{5}{|c|}{ Resistance/Susceptibility (the degree of response to infection) } \\
\hline & & \multicolumn{5}{|c|}{ Synchytrium endobioticum pathotypes } \\
\hline & & 1 (D1) common & 11 (Mizhhirya) & 13 (Rakhiv) & 18 (Yasinia) & 22 (Bystrets) \\
\hline 35. & Zaviia & $\mathrm{R}(2,0)$ & $\mathrm{S}(4,6)$ & $S(4,6)$ & $\mathrm{S}(4,8)$ & $\mathrm{R}(2,8)$ \\
\hline 36. & Tyras & $\mathrm{R}(2,8)$ & $\mathrm{R}(2,8)$ & $\mathrm{S}(4,8)$ & $S(4,6)$ & $S(4,6)$ \\
\hline 37. & Zheran & $\mathrm{R}(2,8)$ & $\mathrm{R}(2,8)$ & $S(4,6)$ & $\mathrm{S}(4,8)$ & $S(4,6)$ \\
\hline 38. & Zvizdal & $\mathrm{R}(2,0)$ & $\mathrm{R}(3,0)$ & $S(4,6)$ & $\mathrm{S}(4,8)$ & $\mathrm{S}(4,8)$ \\
\hline 39. & Dorohyn & $\mathrm{R}(2,8)$ & $\mathrm{S}(4,6)$ & $\mathrm{S}(4,8)$ & $\mathrm{S}(4,6)$ & $\mathrm{S}(4,6)$ \\
\hline 40. & Karlik & $\mathrm{R}(2,8)$ & $\mathrm{S}(4,6)$ & $S(4,6)$ & $\mathrm{S}(4,8)$ & $\mathrm{S}(4,6)$ \\
\hline 41. & Teteriv & $\mathrm{R}(3,0)$ & $\mathrm{S}(5,0)$ & $\mathrm{S}(5,0)$ & $\mathrm{S}(5,0)$ & $\mathrm{S}(4,8)$ \\
\hline Control & Poliska rozheva & $\mathrm{S}(4,8)$ & $\mathrm{S}(5,0)$ & $\mathrm{S}(5,0)$ & $\mathrm{S}(5,0)$ & $\mathrm{S}(4,8)$ \\
\hline Control & Lorkh & $\mathrm{S}(4,8)$ & $\mathrm{S}(5,0)$ & $\mathrm{S}(5,0)$ & $\mathrm{S}(5,0)$ & $\mathrm{S}(4,8)$ \\
\hline
\end{tabular}

Note. "R" - resistant to S. endobioticum pathotypes; "S" - susceptible S. endobioticum pathotypes. * The degree of response to infection - the degree of resistance (between 1 and 3) or the degree of susceptibility (between 4 and 5).

(Kalynivska Vernisazh, Khortysia, Dyvo, Malynska bila, Partner) and five - to all four aggressive pathotypes (Bazys, Hlazurna, and Solokha, Bozhedar and Santarka).

Multiple resistance to common and all four aggressive pathotypes was noted for three potato varieties, bred by the Institute for Potato Research, NAAS (Bazys, Hlazurna, and Solokha) and two - bred by the Polissia Experimental Department of the Institute for Potato Research, NAAS (Bozhedar and Santarka). These varieties are recommended for the breeding process as resistance sources, to be included in seed multiplication programs and to be introduced in the infested areas in the western region of Ukraine.

\section{CONCLUSIONS}

In 2011-2017, the preliminary climatic chamber and greenhouse tests showed 3,389 potato varieties to be resistant to the common pathotype $1\left(\mathrm{D}_{1}\right)$ of the potato wart pathogen Synchytrium endobioticum. The national testing program under field conditions confirmed the resistance of 130 potential potato varieties, selected from the above mentioned resistant breeding material, to common pathotype 1 of $S$. endobioticum: the list of these potential varieties was given to the institutions, wherefrom the breeding material had originated, with the indication of resistance characteristics to $S$. endobioticum and recommendations of their registration and further introduction in the spreading areas of potato wart disease in Ukraine. In 2011-2017 the national breeding program targeted on resistance against $S$. endobioticum was the most effective against pathotype 11 (49\% of samples tested resistant), whereas it was the least effective against pathotype 18 (30\% resistant). It was speculated that such a dissimilarity may be related to the differences in the genetic material used in the breeding process at various institutions, and which may be the subject of further analysis in order to improve the results of breeding programs. Testing for resistance of potential varieties, selected from the breeding material to common pathotype 1 and local (aggressive) pathotypes of potato wart, demonstrated that 64 samples were resistant to pathotype 11 (Mizhhirya); 59 samp-les - resistant to pathotype 13 (Rakhiv); 39 - resistant to pathotype 18 (Yasinia), and 59 samples - resistant to pathotype 22 (Bystrets). These samples were recommended for use in breeding programs and to be registered and cultivated in the potato wart infested areas in the western region of Ukraine. Noteworthy are three existing, registered Ukrainian potato varieties, bred by the Institute for Potato Research, NAAS (Bazys, Hlazurna and Solokha) and two varieties, bred by the Polissia Experimental Department of IP NAAS (Bozhedar and Santarka), which have multiple resistance both to common pathotype $1\left(\mathrm{D}_{1}\right)$ and the four local aggressive pathotypes (11, 13,18 and 22) of $S$. endobioticum. These varieties are recommended for the breeding process as resistance sources, to be included in seed multiplication programs and to be introduced in the infested areas in the western region of Ukraine. 


\section{ZELYA et al.}

\section{Відбір сортів картоплі з комплексною стійкістю до раку Synchytrium endobioticum (Schilbersky) Percival у західному регіоні України}

А. Г. Зеля ${ }^{1}$, Г. В. Зеля ${ }^{1}$, Т. М. Олійник ${ }^{2}$, Л. А. Пилипенко ${ }^{3}$, М. П. Соломійчук ${ }^{1}$, Р. О. Кордулян ${ }^{1}$, А. М. Скорейко ${ }^{1}$, Ю. М. Бундук ${ }^{1}$, В. М. Гунчак ${ }^{1}$

${ }^{1}$ Українська науково-дослідна станція карантину рослин ІЗР НААН

${ }^{2}$ Інститут картоплярства НААН

${ }^{3}$ Національна академія аграрних наук України

e-mail: ukrndskr@gmail.com, liliya.pylypenko@gmail.com

Мета. Оцінити селекційний матеріал картоплі на стійкість до патотипів рака картоплі Synchytrium endobioticum (Schilbersky) Percival, поширених в Україні $\left(1\left(\mathrm{D}_{1}\right), 11,13,18\right.$ та 22), та виділити стійкі сорти для впровадження у вогнищах хвороби i використання у селекційному процесі в якості джерел стійкості до збудника. Методи. Оцінку селекційного матеріалу на стійкість до звичайного $1\left(\mathrm{D}_{1}\right) \mathrm{i}$ агресивних патотипів збудника раку картоплі $(11,13,18$ та 22) проводили за методами Spieckermann та Glynne-Lemmerzahl (EPPO Standard PM7/28(2)) та польових умовах на природному інфекційному фоні у Чернівецькій, Закарпатській та Івано-Франківській області за загальноприйнятими методиками, адаптованими на національних потреб. Результати. Із тестованих впродовж 2011-2017 pp. у західному регіоні України 3736 зразків картоплі, отриманих від шести науково-дослідних та селекційних установ України, виділено 3389 зразків картоплі, стійких до звичайного патотипу $1\left(\mathrm{D}_{1}\right)$ збудника раку $S$. endobioticum у попередньому випробуванні, та 130 у державному польовому. Оцінено 41 сорт картоплі і виділено 5 сортів картоплі 3 комплексною стійкістю до 5 патотипів збудника $\left(1\left(\mathrm{D}_{1}\right), 11,13,18\right.$ та 22) (Базис, Глазурна, Солоха, Божедар і Сантарка). Висновки. Виділені за підсумками всіх випробувань стійкі проти звичайного патотипу збудника раку сортозразки картоплі рекомендовані до державної реєстрації із зазначенням характеристики стійкості проти збудника та подальшого районування у вогнищах хвороби в Україні. Відзначено, що впродовж 2011-2017 pp. найбільш результативною в Україні виявилась селекційна програма спрямована на одержання сортозразків картоплі стійких до ураження агресивним патотипом $S$. endobioticum 11 (49 \% стійких зразків серед усіх тестованих) і найбільш складною - до патотипу 18 (30 \%). Причиною такого стану речей може бути відмінність генетичного матеріалу установ-оригінаторів, залученого до селекційного процесу, що може бути предметом подальшого аналізу з метою виявлення перспективних джерел стійкості та корегування селекційних програм. Сорти картоплі Базис, Глазурна, Солоха, Божедар і Сантарка із комплексною стійкістю до звичайного па- тотипу $1\left(\mathrm{D}_{1}\right)$ та чотирьох місцевих агресивних патотипів $S$. endobioticum (патотипи 11, 13, 18 та 22) рекомендовані для залучення в селекційний процес в якості джерел стійкості та впровадження у вогнищах раку картоплі у західному регіоні України.

Ключові слова: картопля, рак, патотипи, тестування, стійкість, селекція.

\section{Отбор сортов картофеля с комплексной устойчивостью к раку Synchytrium endobioticum (Schilbersky) Percival в западном регионе Украины}

А. Г. Зеля, Г. В. Зеля, Т. Н. Олийнык, Л. А. Пилипенко, М. П. Соломійчук, Р. О. Кордулян, А. Н. Скорейко, Ю. М. Бундук, В. М. Гунчак

${ }^{1}$ Украинская научно-исследовательская станция
карантина ростений ИЗР НААН
${ }^{2}$ Институт картофелеводства НААН
${ }^{3}$ Национальная академия аграрных наук Украины e-mail: ukrndskr@gmail.com, liliya.pylypenko@gmail.com

Цель. Оценить селекционный материал картофеля на устойчивость к патотипам рака картофеля Synchytrium endobioticum Schilbersky Perc., распространенных в Украине $(1,11,13,18$ и 22), и выделить устойчивые сорта для внедрения в очагах болезни и использования в селекционном процессе в качестве источников устойчивости к возбудителю. Методы. Оценку селекционного материала и зарегистрированных сортов картофеля на устойчивость к обычному $1\left(\mathrm{D}_{1}\right)$ и агрессивным (11, $13,18,22)$ патотипам рака картофеля проводили по методу Spieckermann и Glynne-Lemmerzahl (ЕРPO Standard PM7/28(2)) и в полевых условиях на природном инфекционном фоне в Черновицкой, Закарпатской и Ивано-Франковской областях по общепринятым методам, адаптированных к национальным условиям. Результаты. Из тестированных на протяжении 20112017 гг. в западном регионе Украины 3736 образцов картофеля, полученных из шести научно-исследовательских и селекционных учреждений Украины, выделено 3389 образцов картофеля, устойчивых к обычному патотипу $1\left(\mathrm{D}_{1}\right)$ рака картофеля $S$. endobioticum в предварительном испытании и 130 - в государственном. Оценено 41 сорт картофеля и выделено 5 с комплексной устойчивостью ко всем местным патотипам возбудителя $1\left(\mathrm{D}_{1}\right), 11,13,18$ и 22 (Базис, Глазурна, Солоха, Божедар и Сантарка). Выводы. Выделенные по результатам всех испытаний устойчивые против обычного патотипа $1\left(\mathrm{D}_{1}\right)$ возбудителя рака картофеля сортообразцы картофеля рекомендованы для государственной регистрации и дальнейшего районирования в очагах болезни в Украине. Отмечено, что на протяжении 2011-2017 гг. наиболее результативной в Украине была селекционная программа, направленная на получение сортообразцов картофеля устойчивых к 
заражению агрессивным патотипом S. endobioticum 11 (49 \% устойчивых образцов среди всех испытуемых) и наиболее сложной - к патотипу 18 (30\%). Причиной такого положения дел могут быть отличия в генетическом материале, использованном в селекционном процессе различных учреждений, что может быть предметом дальнейшего анализа с целью выявления перспективных источников устойчивости и коррекции селекционных программ. Сорта картофеля Базис, Глазурна, Солоха, Божедар и Сантарка с комплексной устойчивостью к обычному патотипу $1\left(\mathrm{D}_{1}\right)$ и четырем местным агрессивным патотипам $S$. endobioticum $(11,13,18$ та 22) рекомендованы для использования в селекционном процессе в качестве источников устойчивости и внедрения в очагах рака картофеля в западном регионе Украины.

Ключевые слова: картофель, рак, патотипы, оценка, устойчивость, селекция.

\section{REFERENCES}

1. FAOSTAT. Statistics Division. Food and Agriculture Organization of the United Nations. (available online). http://www.fao.org/faostat/en/\#data

2. State Statistics Service of Ukraine. Statistical information. Economic statistics. Economic activity. Agriculture, forestry and fishery. (available online). http://www. ukrstat.gov.ua/

3. Obidiegwu JE, Flath K, Gebhardt C. Managing potato wart: a review of present research status and future perspective. Theor. Appl. Genet. 2014;127(4):763-80. doi: 10.1007/s00122-014-2268-0.

4. PM 7/28 (2) Synchytrium endobioticum. Bulletin OEPP/ EPPO Bulletin. 2017;47(3):420-40. doi: 10.1111/epp.12441.

5. Baayen RP, Cochius G, Hendriks H, Meffert JP, Bakker $J$, Bekker M, van den Boogert PHJF, Stachewicz H, van Leeuwen GCM. History of potato wart disease in Europe - a proposal for harmonisation in defining pathotypes. Eur. J. Plant Pathol. 2006;116,21-31. doi: 10.1007/ s10658-006-9039-y.

6. Bojnansky $V$. Potato wart pathotypes in Europe from an ecological point of view. Bulletin OEPP/EPPO Bulletin. 1984;14(2):141-6. doi: org/10.1111/j.1365-2338. 1984.tb01861.x
7. EPPO (2018) EPPO Global Database (available online). https://gd.eppo.int

8. Melnik PA. Wart disease of potato, Synchytrium endobioticum (Schilbersky) Percival. EPPO Technical documents. Paris, 1998;1032.

9. Przetakiewicz J. The Viability of Winter Sporangia of Synchytrium endobioticum (Schilb.) Perc. from Poland. Amer. J. Potato Res. 2015;92(6): 704-8.

10. Saltykova LP. Identification of potato wart disease pathogen's pathotypes. Zaschita rasteniy. 1988;11:37-8.

11. State Service of Ukraine for Food Safety and Consumer Protection. An overview of the distribution of quarantine organisms in Ukraine as of 01.01.2018. (available online). http://www.consumer.gov.ua/ContentPages/Oglyad Poshirennya_Karantinnikh_Organizmiv_V_Ukraini/219/

12. Obidiegwu $\overline{J E}$, Sanetomo $\bar{R}$, Flath $K$, Tacke E, Hofferbert $H$-R, Hofmann A, Walkemeier B, Gebhardt C. Genomic architecture of potato resistance to Synchytrium endobioticum disentangled using SSR markers and the $8.3 \mathrm{k}$ SolCAP SNP genotyping array. BMC Genetics. 2015; 16:38. doi: 10.1186/s12863-015-0195-y.

13. Flath K, Przetakiewicz J, van Rijswick PCJ, Ristau V, van Leeuwen GCM. Interlaboratory tests for resistance to Synchytrium endobioticum in potato by the GlynneLemmerzahl method. Bulletin OEPP/EPPO Bulletin. 2014;44(3):510-7. doi: 10.1111/epp.12167.

14. Ballvora A, Flath K, Lübeck J, Strahwald J, Tacke E, Hofferbert HR, Gebhardt $C$. Multiple alleles for resistance and susceptibility modulate the defense response in the interaction of tetraploid potato (Solanum tuberosum) with Synchytrium endobioticum pathotypes 1, 2, 6 and 18. Theor. Appl. Genet. 2011;123(8):1281-92. doi: 10. 1007/s00122-011-1666-9.

15. Groth J, Song Y, Kellermann A, Schwarzfischer A. Molecular characterisation of resistance against potato wart races 1, 2, 6 and 18 in a tetraploid population of potato (Solanum tuberosum subsp. tuberosum). J. Appl. Genet. 2013;54(2):169-78. doi: 10.1007/s13353-0130141-5.

16. Cakir E, Van Leeuwen GCM, Flath K, Meffert JP, Janssen WAP, Maden S. Identification of pathotypes of Synchytrium endobioticum found in infested fields in Turkey. Bulletin OEPP/ EPPO Bulletin. 2009;39(2):1758. doi: org/10.1111/j.1365-2338.2009.02285.x. 